\title{
High Grade B-Cell Lymphoma
}

National Cancer Institute

\section{Source}

National Cancer Institute. High Grade B-Cell Lymphoma. NCI Thesaurus. Code C138211.

A term that refers to high grade B-cell lymphoma, not otherwise specified or high grade B-cell lymphoma with MYC and BCL2 and/or BCL6 rearrangements. 